\title{
PENERAPAN MODEL PEMBELAJARAN KOOPERATIF TIPE STAD DALAM MENINGKATKAN MINAT DAN HASIL BELAJAR AKUNTANSI (Studi pada Siswa Kelas XI Akuntansi SMK Negeri 2 Palu)
}

\author{
Suryani ${ }^{1}$ \\ ${ }^{1}$ Guru SMK Negeri 2 Palu
}

\begin{abstract}
The problem of this research is the low of student interest and result of a study of accounting at the students of the class of XI AK 1, SMKN 2 Palu. This problem appears since the teaching method is still teacher-centre-learning. This problem might be solved by using the Student Achievement Division (STAD) cooperative learning model. This study is a classroom action research that aims to increase interest and learning outcomes of accounting in students of class XI SMKN 2 Palu. Research carried out in two cycles which each cycle consists of four stages: planning, action implementation, observation and reflection. The results indicate that STAD type cooperative learning model used by the teacher is done very well and student interest in learning generally is very good especially on cycle II. It can be concluded that the use of STAD type cooperative learning model can increase interest and learning outcomes accounting students in class XI AK 1 SMKN 2 Palu.
\end{abstract}

Keywords: STAD Type, Cooperative Learning Model, Study Interest, Study Result, Accounting

\begin{abstract}
ABSTRAK
Permasalahan penelitian ini adalah rendahnya minat dan hasil belajar akuntansi pada siswa kelas XI Ak 1 SMKN 2 Palu. Hal ini disebabkan oleh pembelajaran yang digunakan masih berpusat pada guru. Masalah tersebut dapat diatasi dengan menggunakan model pembelajaran kooperatif tipe Student Achievement Division (STAD). Penelitian ini merupakan penelitian tindakan kelas yang bertujuan untuk meningkatkan minat dan hasil belajar akuntansi pada siswa kelas XI SMKN 2 Palu. Penelitian dilaksanakan dalam dua siklus, setiap siklus terdiri dari empat tahap yaitu: perencanaan, pelaksanaan tindakan, pengamatan dan refleksi. Berdasarkan hasil observasi menunjukkan bahwa model pembelajaran kooperatif tipe STAD yang digunakan guru terlaksana dengan sangat baik dan minat siswa selama pembelajaran pada umunya sangat baik terutama pada siklus II. Untuk itu dapat disimpulkan bahwa penggunaan model pembelajaran kooperatif tipe STAD dapat meningkatkan minat dan hasil belajar akuntansi pada siswa kelas XI Ak 1 SMKN 2 Palu.
\end{abstract}

Kata kunci: Tipe STAD, Model Pembelajaran Kooperatif, Minat Belajar, Hasil Belajar, Akuntansi

Jurnal Akun Nabelo: Jurnal Akuntansi Netral, Akuntabel, Objektif Volume 1/Nomor 1/Juli 2018 Jurusan Akuntansi FE-Universitas Tadulako

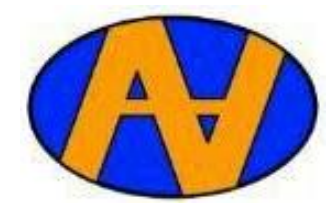




\section{A. PENDAHULUAN}

Mata pelajaran akuntansi adalah mata pelajaran produktif di SMK Negeri 2 Palu, yang masih sulit dipahami oleh siswa. Hasil belajar selama ini yang diperoleh siswa belum mencapai persentase ketuntasan kelas minimal (KKM) yang dipersyaratkan yaitu lebih besar atau sama dengan 70\%. Hal ini disebabkan oleh pembelajaran yang digunakan masih berpusat pada guru. Aktivitas siswa sebatas pada mendengar melihat dan mencatat. Akibatnya, siswa lebih banyak melakukan aktivitas lain yang tidak ada hubungannya dengan materi yang diajarkan oleh guru. Keadaan ini menyebabkan siswa kurang berminat dalam belajar akuntansi, merasa jenuh, bosan dan bahkan ada diantara mereka mengganggu temannya yang sedang fokus belajar. Selain itu, mata pelajaran akuntansi merupakan hal yang baru dipelajari oleh siswa pada saat mereka belajar di SMKN 2 yang mana berbeda dengan mata pelajaran lain yang sudah diajarkan sejak SMP, misalnya Bahasa Inggis, Matematika dan lain-lain.

Telah diketahui bahwa pembelajaran akuntansi di SMK Negeri 2 Palu lebih banyak bersifat studi kasus, seperti siswa dihadapkan pada sejumlah kasus pembukuan dari suatu perusahaan. Kesulitan yang dialami oleh siswa pada kasus tersebut adalah sulitnya mereka memahami konsep pencatatan transaksi ke dalam jurnal. Sejumlah siswa tidak mampu menelaah kasus transaksi dalam pembukuan, sehingga tidak mampu mencatatnya ke dalam jurnal. Jika siswa telah mampu mencatat transaksi ke dalam jurnal, maka siswa tersebut telah memiliki kompetensi dalam pencatatan transaksi.

Salah satu upaya yang dilakukan untuk mengatasi masalah tersebut adalah dengan menggunakan model pembelajaran kooperatif tipe STAD (Student Achievement Decision). Model pembelajaran ini dirancang dalam bentuk kelompok agar siswa dapat saling bekerja sama dalam menyelesaikan masalahnya (Nur, 2005). Keterlibatan setiap anggota kelompok dalam bekerja menunjukkan tingginya aktivitas siswa dalam belajar yang mana merupakan salah satu prinsip keberhasilan pembelajaran di sekolah (Darmodjo, 1993). Keterlibatan siswa secara aktif dalam pembelajaran akan membangkitkan minat untuk mau belajar. Minat belajar adalah upaya yang mendorong seseorang untuk mau melakukan sesuatu (Sudirman, 2002). Tingginya aktivitas dan adanya kerja sama diantara siswa yang menggunakan prinsip sehidup semati dalam menyelesaikan masalah akan menjadikan pembelajaran lebih efektif (Sukarmin, 2002). Prinsip sehidup semati artinya setiap anggota kelompok memiliki tanggung jawab membantu anggota kelompok yang mengalami kesulitan (Trianto, 2009). Pembelajaran akan menjadi efektif karena siswa belajar dalam situasi yang menyenangkan (Mulyasa, 2005).

\section{B. METODE PENELITIAN}

Jenis penelitian ini adalah penelitian tindakan kelas partisipan yang menggunakan pendekatan kualitatif. Penelitian dilakukan dalam bentuk putaran (siklus) yang disesuaikan dengan indikator keberhasilan yang dicapai. Indikator keberhasilan yang ditetapkan di sekolah untuk mata pelajaran Akuntansi adalah persentase ketuntasan kelas minimal yang diperoleh melebihi 70\%. Setiap siklus terdiri dari beberapa tahap dan setiap tahap terdiri dari sejumlah kegiatan dilakukan yang telah dirancang dan dipersiapkan sebelumnya. Subjek penelitian adalah siswa kelas XI Ak 1 SMKN 2 Palu yang mana berjumlah 32 siswa. Ada dua jenis data yang dikumpulkan yaitu data kualitatif dan data kuantitatif. Data kualitatif yaitu nilai pelaksanaan 
pembelajaran dan minat belajar akuntansi siswa selama proses pembelajaran yang mana dikumpul dengan menggunakan lembar observasi. Data kuantitatif yaitu data hasil belajar akuntansi dengan mengggunakan tes. Analisis data dilakukan dengan mengacu pada Miles dan Huberman (1992) yaitu mereduksi data, menyajikan data dan menyimpulkan data.

\section{HASIL DAN PEMBAHASAN}

Penelitian dilaksanakan dalam dua siklus dan masing-masing siklus diperoleh hasil sebagai berikut.

\section{C.1 Hasil Observasi}

Hasil yang diperoleh pada tahap ini adalah mengobservasi pelaksanaan pembelajaran yang menggunakan model pembelajaran kooperatif tipe STAD. Kegiatan yang diobservasi adalah aktivitas guru dan minat siswa dalam belajar akuntansi.

\section{C.1.1 Aktivitas Guru}

Observasi aktivitas guru bertujuan untuk melihat kesesuaian pelaksanaan pembelajaran dengan rencana pembelajaran. Hasil observasi terlihat pada Tabel 1.

Tabel 1

Hasil Observasi Aktivitas Guru pada Siklus I dan Siklus II

\begin{tabular}{|c|c|c|c|}
\hline \multirow{2}{*}{ No. } & \multirow[b]{2}{*}{ Aspek yang Diamati } & \multicolumn{2}{|c|}{ NILAI } \\
\hline & & Siklus I & Siklus II \\
\hline \multirow[t]{4}{*}{$\mathrm{I}$} & Pendahuluan & & \\
\hline & 1. Menyampaikan tujuan pembelajaran & $\begin{array}{l}\text { Sangat } \\
\text { Baik }\end{array}$ & $\begin{array}{l}\text { Sangat } \\
\text { Baik }\end{array}$ \\
\hline & 1. Memotivasi siswa & $\begin{array}{l}\text { Sangat } \\
\text { Baik }\end{array}$ & $\begin{array}{l}\text { Sangat } \\
\text { Baik }\end{array}$ \\
\hline & $\begin{array}{l}\text { 2. Mengaitkan pembelajaran dengan pengetahuan awal } \\
\text { siswa/prasyarat }\end{array}$ & $\begin{array}{l}\text { Sangat } \\
\text { baik }\end{array}$ & $\begin{array}{l}\text { Sangat } \\
\text { Baik }\end{array}$ \\
\hline \multirow[t]{7}{*}{ II } & Kegiatan Inti & & \\
\hline & $\begin{array}{l}\text { 1.Mempersiapkan materi pokok yang mendukung tugas } \\
\text { belajar kelompok dengan cara menyampai-kan materi } \\
\text { ajar. }\end{array}$ & $\begin{array}{l}\text { Sangat } \\
\text { baik }\end{array}$ & $\begin{array}{l}\text { Sangat } \\
\text { Baik }\end{array}$ \\
\hline & 2.Mengatur siswa dalam kelompok-kelompok belajar & Baik & $\begin{array}{l}\text { Sangat } \\
\text { Baik }\end{array}$ \\
\hline & $\begin{array}{l}\text { 3.Membimbing siswa dalam mengerjakan LKS dengan } \\
\text { benar }\end{array}$ & Baik & $\begin{array}{l}\text { Sangat } \\
\text { Baik }\end{array}$ \\
\hline & 4.Mengawasi setiap kelompok secara bergiliran & Kurang & $\begin{array}{l}\text { Sangat } \\
\text { Baik }\end{array}$ \\
\hline & $\begin{array}{l}\text { 5.Memberi bantuan kepada kelompok yang mengalami } \\
\text { kesulitan }\end{array}$ & Baik & $\begin{array}{l}\text { Sangat } \\
\text { Baik }\end{array}$ \\
\hline & 6.Memberikan resitasi/umpang balik & Baik & $\begin{array}{l}\text { Sangat } \\
\text { Baik }\end{array}$ \\
\hline \multirow[t]{4}{*}{ III } & Penutup & & \\
\hline & 1.Membimbing siswa membuat rangkuman & Baik & $\begin{array}{l}\text { Sangat } \\
\text { Baik }\end{array}$ \\
\hline & $\begin{array}{l}\text { 2.Memberikan penghargaan pada kelompok yang } \\
\text { terbaik dan motivasi pada kelompok yang kurang baik }\end{array}$ & Baik & $\begin{array}{l}\text { Sangat } \\
\text { Baik }\end{array}$ \\
\hline & 3.Memberikan tugas rumah. & $\begin{array}{l}\text { Sangat } \\
\text { baik }\end{array}$ & $\begin{array}{l}\text { Sangat } \\
\text { Baik }\end{array}$ \\
\hline
\end{tabular}

Sumber: Diolah penulis, 2018 


\section{C.1.2 Minat Siswa}

Minat siswa selama proses pembelajaran dilihat dari sikap mereka selama proses pembelajaran berlangsung diantaranya adalah sikap minat terhadap materi ajar, keaktifan, kerja sama, kejujuran, kedisiplinan dan tanggung jawab selama proses pembelajaran. Berdasarkan penilaian yang dilakukan oleh pengamat, hasilnya dapat dilihat pada Tabel 2.

Tabel 2

Minat Siswa Belajar Akuntansi Siklus I dan Siklus II

\begin{tabular}{|c|l|l|l|}
\hline \multirow{2}{*}{ No. } & \multicolumn{2}{|c|}{ Aspek yang Diamati } & \multicolumn{2}{c|}{ Siklus II } \\
\cline { 3 - 4 } & & \multicolumn{1}{c|}{ Siklus I } & \multicolumn{1}{c|}{ NILAI } \\
\hline 01 & Minat terhadap materi Ajar & Sangat Baik & Sangat Baik \\
\hline 02 & Aktif dalam pembelajaran & Baik & Sangat baik \\
\hline 03 & Saling kerja sama & Baik & Sangat Baik \\
\hline 04 & Jujur dalam pembelajar-an & Baik & Baik \\
\hline 05 & Disiplin dalam pembelajar-an & Baik & Baik \\
\hline 06 & $\begin{array}{l}\text { Bertanggung jawab dalam } \\
\text { pembelajaran }\end{array}$ & Sangat Baik & Sangat Baik \\
\hline
\end{tabular}

Sumber: Diolah penulis, 2018

\section{C.2 Hasil Belajar Siswa}

Pada akhir pelaksanaan pembelajaran setiap siklus dilaksanakan tes akhir siklus. Hasil yang diperoleh dapat dilihat pada Tabel 3.

Tabel 3

Skor Penilaian Tes Akhir Siklus I dan Siklus II

\begin{tabular}{|l|l|l|l|}
\hline \multirow{2}{*}{ No. } & \multicolumn{1}{|c|}{ Aspek yang dinilai } & \multicolumn{2}{|c|}{ HASIL } \\
\cline { 3 - 4 } & & Siklus I & Siklus II \\
\hline 1. & Skor tertinggi & 100 (3 Orang) & $\begin{array}{l}100 \\
\text { (4 Orang) }\end{array}$ \\
\hline 2. & Skor terendah & 55 (2 Orang) & $\begin{array}{l}70 \\
(9 \text { Orang) }\end{array}$ \\
\hline 3. & Skor rata-rata & 73 & 80,7 \\
\hline 4. & Banyaknya siswa yang tuntas & 22 Orang & 28 Orang \\
\hline 5. & Prosentase ketuntasan kelassikal & $69 \%$ & $88 \%$ \\
\hline
\end{tabular}

Sumber: Diolah penulis, 2018

Hasil belajar yang diperoleh pada siklus I belum mencapai indikator keberhasilan, masih lebih kecil dari $70 \%$ yang dipersyaratkan. Untuk itu dilakukan siklus II dengan cara merevisi beberapa kekurangan yang terjadi pada siklus I. Walaupun pembelajaran yang dilakukan oleh guru pada umumnya telah terlaksana dengan baik. Hal yang menjadi fokus perhatian untuk direvisi pada siklus I adalah kegiatan guru dalam mengawasi setiap kelompok masih dinilai kurang. Hal itu disebabkan oleh jumlah anggota setiap kelompok cukup besar yaitu lima orang setiap kelompok dan bahkan ada kelompok yang memiliki enam orang anggota.

Berdasarkan hasil yang diperoleh pada siklus II sudah memenuhi indikator kinerja yang sudah ditetapkan yaitu persentase ketuntasan kelassikal minimal lebih besar dari $70 \%$. Skor rata-rata yang diperoleh pada siklus II lebih besar daripada skor rata-rata yang diperoleh pada siklus I. Tingginya skor rata-rata yang diperoleh pada siklus II diduga disebabkan oleh bertambahnya tingkat kemahiran guru dalam menggunakan model pembelajaran kooperatif tipe STAD. Hasil yang diperoleh pada penelitian ini juga sejalan dengan hasil penelitian Risdiyawati (2012) yang 
menunjukkan bahwa model pembelajaran kooperatif tipe STAD meningkatkan motivasi dan hasil belajar akuntansi pada siswa kelas XI IPS 4 SMAN 1 Imogiri. Walaupun hasil yang diperoleh rata-rata sangat baik dilihat dari pelaksanaan pembelajaran oleh guru serta minat siswa, demikian pula hasil belajar siswa sudah melebihi dari indikator kinerja yang ditetapkan. Akan tetapi masih ada kendala yang dialami dalam pelaksanaan pembelajaran terutama pada siklus I. Kendala tersebut berupa lamanya waktu yang tersita pada saat pembentukan kelompok kooperatif. Bukan hanya waktu yang tersita, tetapi juga terjadi sedikit keributan akibat setiap individu mencari anggota kelompoknya. Kendala yang lain ditemukan pada siklus I adalah masih ada anggota kelompok yang bersifat pasif. Pasifnya anggota kelompok tersebut diduga disebabkan oleh jumlah anggota setiap kelompok yang banyak (sekitar lima orang). Semua kendala yang dialami pada siklus I telah teratasi sehingga pembelajaran pada siklus II berjalan dengan sangat baik.

\section{PENUTUP}

Berdasarkan hasil penelitian yang dilakukan maka dapat disimpulkan bahwa model pembelajaran kooperatif tipe STAD dapat meningkatkan minat dan hasil belajar akuntansi pada siswa kelas XI Ak 1 SMKN2 Palu. Untuk mendapatkan hasil yang lebih baik pada penggunaan model pembelajaran kooperatif tipe STAD sebaiknya:

1. Pembentukan kelompok dilakukan lebih awal sebelum pelaksanaan pembelajaran agar penggunaan waktu lebih efisien dan efektif.

2. Jumlah anggota setiap kelompok sebaiknya dibatasi tiga orang, agar terhindar dari adanya anggota kelompok yang bersifat pasif dan tidak saling menggganggu diantara teman.

\section{DAFTAR PUSTAKA}

Darmodjo, H., 1993, Pendidikan IPA 2, Depdikbud Direkjend Pend. Tinggi, Proyek Pembinaan Tenaga Kependidikan, Jakarta.

Harlen, W., 1985, Teachingand Learning Primary Science, London: Harper and Row Publisher.

Miles, M. B. dan Huberman, A.M., 1992, Analisis Data Kualitatif (terjemahan dari Tjetjep Rohidi), Jakarta: Universitas Indonesia.

Mulyasa, E., 2005, Menjadi Guru Profesional Menciptakan Pembelajaran Kreatif dan Menyenangkan. Cetakan ketiga, Bandung: PT Remaja Rosdakarya.

Nur, Muhammad, 2005. Pembelajaran Kooperatif. Surabaya: Pusat Sains dan Matematika Sekolah UNESA.

Risdiawati, Yana, 2012,Implementasi Model Pembelajaran Kooperatif Tipe STAD untuk Meningkatkan Motivasi dan Hasil Belajar Akuntansi pada Siswa Kelas XI IPA 4 SMAN 1 Imogiri, Yogyakarta: Fakultas Ekonomi Universitas Yogyakarta.

Sudirman, A.M., 2007, Interaksi dan Motivasi Belajar untuk Mengaajar. Jakarta: PT. Raja Grafindo Persada.

Sukarmin, 2002, Pembelajaran Kooperatif. Surabaya: UNESA.

Trianto, 2009, Mendesain Model Pembelajaran Inovatif-Progresif, Konsep, Landasan, dan implementasinya pada KTSP. Jakarta: Prenada Media Group. 